\title{
FAST FORWARD? Reflections on fashion and modernity ${ }^{4}$
}

\author{
Alexandra Verschueren, \\ University of Antwerp \& Antwerp Royal Academy of Fine Arts \\ Antwerp, Belgium
}

\begin{abstract}
This article starts from the striking obsession of the fashion world with innovation and change. Then a systematic attempt is made to relate this feature to the notions of modernity, modernism, and post-modernity. An exploration of these notions in relation to each other leads to a description of the position of fashion in the economy, in a world imbued with social status and politics, in the sphere of individuality and individual needs, and in the context of art and culture. A complex picture emerges in which the artistic and practical problems faced by a designer can be summarized in the following question: what can be made how and where in a sufficiently creative and innovative way, appealing to people's ambivalent needs for identity, conformity, and individual self-expression, and producible in an affordable and ethical manner?
\end{abstract}

Keywords: Fashion; Design; Modernity: Modernism; Postmodernity

\section{An obsession with the future}

The January 2011 issue of Harper's Bazaar was at first sight unremarkable, meeting any fashion magazine reader's basic expectations with cover lines such as "HOW TO DRESS NOW" and "MODERN NEW MOOD". Skipping quickly to the Style section (pp. 39-60), however, we see that editor Clare Coulson gave it a very specific label, The new MODERNITY special, which is repeated in a form resembling a quality sticker on most pages. The section is introduced as follows:

\footnotetext{
${ }^{4}$ The research for this article was carried out under the academic supervision of Kurt Vanhoutte and with the financial support of the Flemish Fund for Scientific Research. Needless to say that I am greatly indebted for both.
} 
At the start of a brand-new year, Bazaar presents a future-fashion special. From advanced fabrics and digital wardrobe services to virtual catwalk shows and the latest apps and websites - plus the hottest new trends and designers - we take a glimpse at stylish things to come.

The superlatives of novelty are hard to miss: brand-new, advanced, latest, hottest, new. And as if that were not enough, there is the promise of getting a look at what is not yet there: future fashion, things to come. This promise is given substance with reference to 'Calvin Klein's futuristic minimalism', a feature on 'The coming storm' (new British designers 'at the forefront of future trends"), and an article - 'Fashion forward' - on the 'brave new world' of new technologies for marketing and buying which everyone will have to embrace in order not to be "stuck in the Iron Age". This is all summed up as "Driven by a combination of smart technology and cool common sense, fashion is undergoing a seachange".

Around the same time, the Barbican Art Gallery in London was exhibiting a retrospective of thirty years of Japanese fashion design with the title 'Future Beauty' (15 October 2010 to 6 February 2011). Thus in the world of fashion even things past can be felt to be sufficiently modern to be related to the future. This may be simply a matter of shifting oneself to a past perspective from which one can then look ahead. But such a conceptual maneuver may even emphasize more than the market-driven and market-driving language of Harper's Bazaar the need for fashion to present itself as really new and reaching into the future.
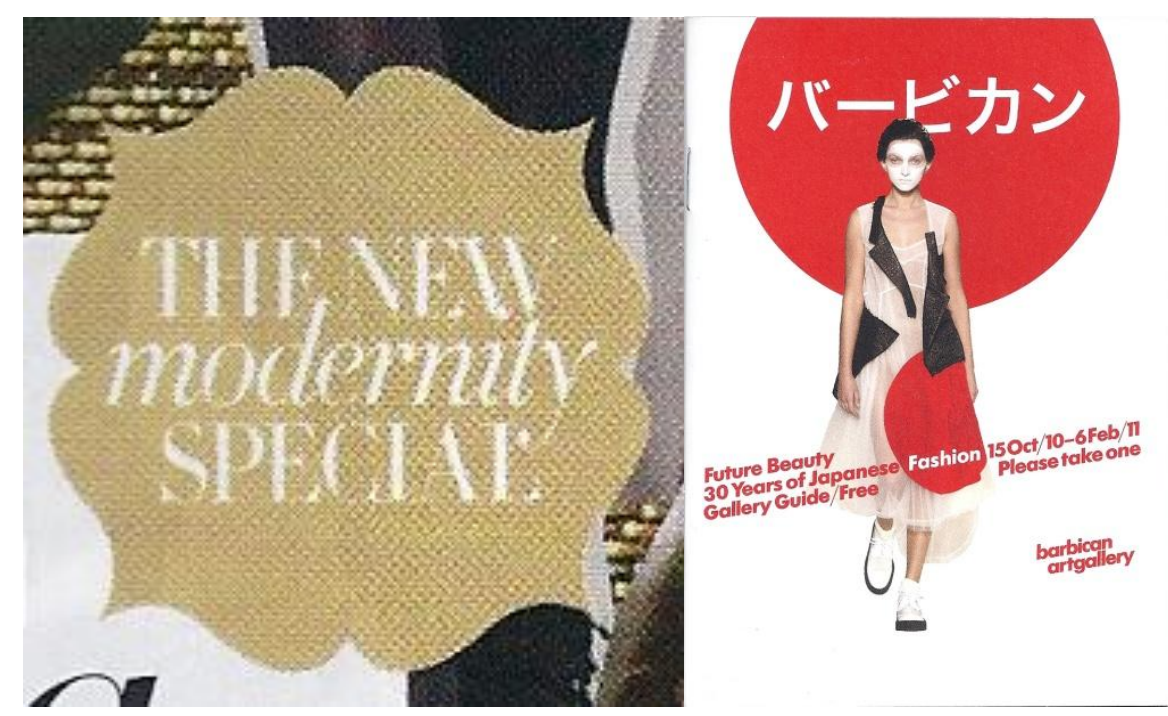

Figure 1: Harper's modernity 'sticker' and the Barbican's exhibition flier 
Such anecdotal facts certainly reveal fashion's somewhat uneasy, because compulsive, relationship with time or, more specifically, with the future and 'modernity'. The uneasiness follows from the fact that the future can never be reached or, as soon as it is reached, it becomes past. As Wilson (2003: vii) puts it, "the 'now' of fashion is nostalgia in the making". Much has been written about fashion and modernity. ${ }^{5}$ But what still seems to be lacking is a compact but explanatory way of situating fashion in the landscape of notions that includes modern, modernity, modernism, but also late modern, postmodern, postmodernism and postmodernity. A modest attempt is made here to fill that gap.

\section{Modern, modernity, modernism}

It is commonplace to say that the concepts just listed do not have the same meaning for everyone. The first task is, therefore, to trace the main differences that may be relevant for situating a specific cultural phenomenon such as fashion. But we need a warning to start with. It is also commonplace to say that for speakers of English the relation between fashion and modernity is less obvious than it already was for Baudelaire in the middle of the $19^{\text {th }}$ century because he spoke French and could therefore easily associate mode, French for 'fashion', with modernité, 'modernity'. That link, though a handy rhetorical tool to start a discussion of the subject, is merely associative and by no means semantic. Mode derives from Latin modus, which simply means 'manner' or 'measure'. It entered French in the $15^{\text {th }}$ century to refer to a way of living and thinking typical for a certain time or place (a sense which is now obsolete except in expressions such as à la mode de ...). Not until the $17^{\text {th }}$ century did it acquire the meaning of fashion in the sense of collective and passing habits of dressing, and in the $18^{\text {th }}$ century it began to refer to fashion as a commercial and industrial activity. ${ }^{6}$ By contrast, the etymological source of moderne (and therefore modernité) is Latin modernus, which was itself derived from the adverb modo, meaning 'recently'. As we shall see later, the link between modern and modernity is not a straightforward one, let alone the link between modernité and mode.

According to Habermas (1983: 3), Hans Robert Jauss (1982) places the first use of modernus in the $5^{\text {th }}$ century "to distinguish the present, which had become officially Christian, from the Roman and pagan past". But the most common use made by historians of the term modern is in the distinction between ancient, medieval, and modern times. The term modern

\footnotetext{
${ }^{5}$ The best-known monographs on the subject are probably Wilson (2003) and Lehmann (2000), but there are also collective volumes devoted to the topic, such as Breward \& Evans (eds) (2005), as well as chapters in other publications (e.g. Faurschou's contribution to Kroker \& Kroker, eds, 1988, or Breward's chapter on the $19^{\text {th }}$ century in his 1995 history of fashion, which gets the subtitle 'Fashion and modernity').

${ }^{6}$ In a succinct form, this history of the French word mode can be found in basic disctionaries such as Le Petit Robert.
} 
then covers the period from the $15^{\text {th }}$ century to the present, and the main characteristics, according to Styles (2005), would be:

- changes in relation to subjectivity (the rise of individualism)

- changes in technology (a scientific and industrial revolution)

- changes in geopolitical relations (an expansion of European global control from Columbus and Vasco da Gama onwards)

One famous historian, Arnold Toynbee, attaches precise dates to the Modern Age, 1475-1875. According to Malpas (2005: 33-34), he saw this period as the rise of humanism, with human beings as the source of knowledge and - through their free will - the source of action, and as culminating in the rationality and freedom ideals of the Enlightenment. For Toynbee (1954), then, this progress declines towards the end of the $19^{\text {th }}$ century when a period of 'postmodern' nationalist conflict and war starts.

\begin{tabular}{|l|l|l|l|l|l|l|r|}
\hline $5^{\text {th }} \mathrm{c}>>$ & $15^{\text {th }} \mathrm{c}$ & $16^{\text {th }} \mathrm{c}$ & $17^{\text {th }} \mathrm{c}$ & $18^{\text {th }} \mathrm{c}$ & $19^{\text {th }} \mathrm{c}$ & $20^{\text {th }} \mathrm{c}$ & present \\
\hline \\
$\begin{array}{l}\text { modern(us) to distinguish the old from the new (originally the Roman pagan past vs. a } \\
\text { European Christian present) }\end{array}$ \\
\hline \\
modern times, as distinguished from ancient and medieval \\
\hline
\end{tabular}

Table 1: The term modern in relation to history

The second term to be explained, modernity, is most often associated with political, social, economic, and cultural developments that started in the $18^{\text {th }}$ century with the Enlightenment, the industrial revolution and the rise of industrial capitalism. A property that is often emphasized is a transition, under the influence of scientific, rational, and emancipatory Enlightenment thinking and of technological progress, from traditional and only slowly changing societies to rapidly self-transforming modern ones. Yet, the properties that Styles (2005) identifies for cultural, technological, and geopolitical developments since at least the $15^{\text {th }}$ century, play such a central role in discussions of modernity, even in its most recent forms, that there may be good reasons to emphasize a strong form of underlying continuity. In fact, many discussions of modernity center around divergent views of continuity and discontinuity. While in line with Horkheimer \& Adorno (1979), one may see $20^{\text {th }}$-century fascisms and totalitarian communism as a direct continuation of an Enlightenment logic that produced rational bureaucratic structures of domination, it is equally easy to side with Toynbee's view of the rise of European nationalisms as the true decline of Enlightenment ideals (thus effectively ending modernity towards the end of the $19^{\text {th }}$ century), or with Habermas (1983) and his normative claim that modernity is still today an unfinished 
project because there is a real need for the further pursuit of Enlightenment ideals in the form of rational debate as a basis for decision-making in public and political life, or of further progress of knowledge, not in the service of power but of moral and social improvement. Continuity, or the lack thereof, becomes even more problematic when the the terms late modernity or postmodernity are introduced. Especially the term postmodernity suggest a real break with preceding modernity. The literature on this topic is extremely complex. ${ }^{7}$ Simplifying more than would be acceptable for other purposes, the basic properties usually singled out for a characterization of postmodernity include:

- $\quad$ at the level of ideas:

○ a questioning of values which Enlightenment thinking held to be universal, including first and foremost rationality itself

$\circ$ the individual subject is no longer seen as a member of a universal human category; there is not so much a clear identity as mutable performances of identity

- emphasis on cultural diversity in a postcolonial world

- at the level of observable and accelerated change:

- fast expansion of scientific knowledge

○ accelerated technological change (especially in communication technology, which is partly responsible for the changed experience of subjectivity)

o rapid shift to an information-based economy (with a strong role for media and mediatization)

○ ever faster expansion and mobility (i.e. 'globalization') in commercial markets Malpas (2005: 38) quotes Lyotard's view of postmodernity as a clear break with the grand Enlightenment narratives of progress, emancipation, and freedom, or as a complete destruction of the project of modernity by economic forces: "[...] the criteria of universalism and emancipation have been replaced by a single criterion: profit". In other words, knowledge no longer serves progress, but economic profit. It has become a commodity, the basis of power; it must serve measurable efficiency. If, however, constant change and selftransformation could be seen as the basic property of modernity, one could as easily say that the postmodern second half of the $20^{\text {th }}$ century is simply a continuation of the same pattern. And if the focus is to be placed on the impact of a profit-driven economy, there may be good reason to side with Wood (1997) and her claim that the notion of growing capitalism provides a better explanation for developments from the $18^{\text {th }}$ century until the present day than the distinction between modernity and postmodernity:

The old Fordism used the assembly line as a substitute for higher cost skilled craftsmen and to tighten the control of the labour process by capital, with the obvious objective of extracting more value from labour. Now, the new technologies are used to

\footnotetext{
${ }^{7}$ My sources, rather than the writings of Jean Baudrillard, Zygmunt Bauman, Fredric Jameson, Charles Jencks, Jean-François Lyotard, and many other major figures, are the more accessible introductions by Delanty (2000) and Malpas (2005).
} 
the same ends: to make products easy and cheap to assemple (how else, for instance, would outsourcing be possible?), to control the labour process, to eliminate or combine various skills in both manufacturing and service sectors, to replace higherwith lower-wage workers, to 'downsize' the workforce altogether - again to extract more value from labour. What is new, then, about this so-called new economy is not that the new technologies represent a unique kind of epochal shift. On the contrary, they simply allow the logic of the old mass production economy to be diversified and extended. Now, the old logic can reach into whoile new sectors, and it can affect types of workers more or less untouched before. (Wood 1997: 550)

Thus in her rejection of postmodernity as a useful explanatory term, Woods basically presents the same analysis as Lyotard: the economy has taken over; or, in her words, capitalism has simply been universalized.

It should be clear that a really simple picture cannot be given. There are many paradoxical tendencies, some of which would point towards discontinuities in development, while others would indicate continuity. There are, for instance, still grand narratives (as pointed out by Malpas 2005): the idea of scientific progress certainly is one (which does not even differ so much from what started in the early stages of modernity); the war on terror may also be one (breaking the initial postmodern idea of the postcolonial coexistence of a diversity of cultures - an idea which is also broken locally by anti-immigrant political movements in western societies). And while communication technologies and travel patterns seem to annihilate borders, new borders are created and old ones reasserted all the time (cf. Augé 2009, who also points at the paradox of a world in which one could theoretically do everything one wants without moving, but where people seem to move more than ever).

\begin{tabular}{|c|c|c|c|c|c|c|}
\hline \multirow[t]{2}{*}{$15^{\text {th }} c>>$} & $18^{\text {th }} \mathrm{c}$ & early $19^{\text {th }} \mathrm{c}$ & late $19^{\text {th }} \mathrm{c}$ & early $20^{\text {th }} \mathrm{c}$ & late $20^{\text {th }} \mathrm{c}$ & present \\
\hline & $\begin{array}{l}\text { moder } \\
- \\
- \\
\text { and ac } \\
\text { bureal } \\
\text { with [ } \\
\text { centur }\end{array}$ & $\begin{array}{l}\text { iew that emp } \\
\text { htenment [ic } \\
\text { nal freedom } \\
\text { trial revoluti } \\
\text { iction, speed } \\
\text { nied by the } \\
\text { structures of } \\
\text { kheimer \& } \\
\text { sm and total }\end{array}$ & $\begin{array}{l}\text { lasizes origi } \\
\text { als of ration } \\
\text { n and capita } \\
\text { mobility, qu } \\
\text { evelopment } \\
\text { organization } \\
\text { dorno] exce } \\
\text { arian comm }\end{array}$ & $\begin{array}{l}\text { in } \\
\text { lity and } \\
\text { sm [mass } \\
\text { k profits] } \\
\text { rational } \\
\text { nd control, } \\
\text { es in } 20^{\text {th }} \text { - } \\
\text { ism) }\end{array}$ & \multicolumn{2}{|c|}{$\begin{array}{l}\text { postmodernity (seen as } \\
\text { differing from modernity } \\
\text { in terms of ideas and } \\
\text { along parameters of } \\
\text { accelerated change) }\end{array}$} \\
\hline \multicolumn{3}{|c|}{$\begin{array}{l}\text { modernity (for Toynbee, who views } \\
\text { the rise of nationalisms as the decline } \\
\text { of Enlightenment ideals) }\end{array}$} & \multicolumn{4}{|c|}{ postmodernity? } \\
\hline
\end{tabular}




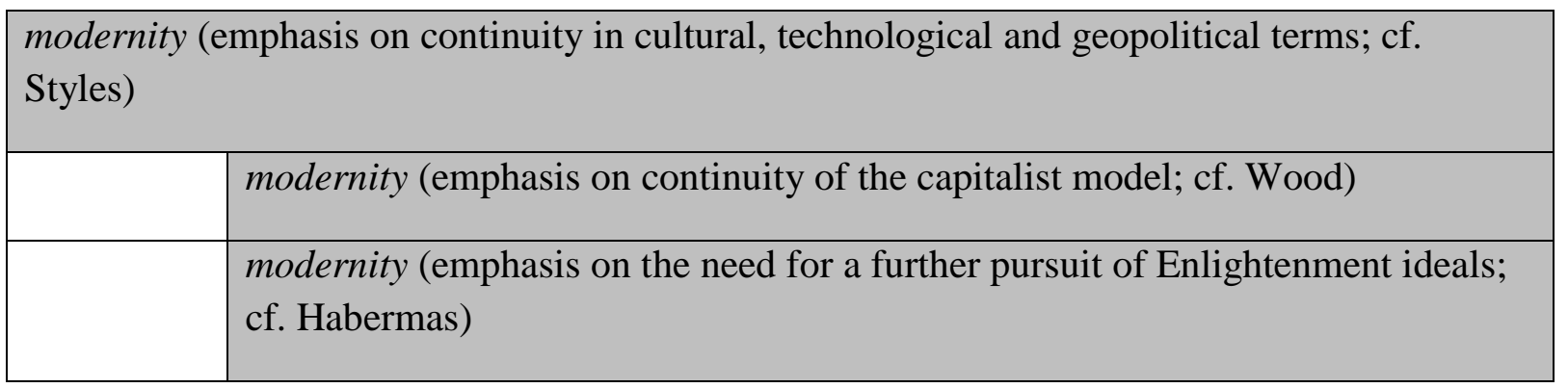

Table 2: Views of modernity and postmodernity

Another pair of terms to be briefly discussed are modernism and postmodernism. These are relatively unambiguous in relation to styles in architecture. Modernism in architecture can be identified with the International Style that was developed between the two Worlds Wars and that was used extensively in the rebuilding of Europe immediately after the Second World War. It is clearly linked to the ideas of modernity, as it emphasized universality and rationality. The idea was to build, on the basis of straightforward principles that could be used anywhere in the world, uniform, ageeable and practical environments that would provide for all the needs of citizens (in sharp contrast to the slum-like conditions of many urban areas before). In doing so, the new materials which industry could provide, were used extensively. Postmodern architecture, by contrast, while continuing the use of advanced materials, reacted to the universalist uniformity of the modernists by reintegrating regional cultural elements, but without copying, and while keeping an ironic distance.

In the arts, the distinction is less simple. Modernist art started in the last decades of the $19^{\text {th }}$ century as a challenge to established forms and styles. The term applies to a range of different movements (including e.g. Surrealism. Dadaism, Futurism) which were all somehow avant-garde. The common aim was to push the limits of art. What is, by contrast, described as postmodernist art, is basically a continuation of such experiments, but without the same sense of seriousness about the role of art in society. Another property of postmodernist art is its 'democratization', in the sense that materials and techniques were introduced that had never before counted as artictic, and that sections of the community were involved that had been excluded from art before. The latter effect was achieved by breaking down the wall between so-called high art and popular culture. In Delanty's words:

Postmodernism in the arts and in questions of aesthetic style is a continuation of early twentieth-century radical modernism in its intensification of the symbolic domain, which is no longer confined to the aesthetic but includes the wider category of the social, the everyday life, and reaches beyond to include history and myth. (Delanty 2000: 133) 
Last but not least - and here a link with the more critical views of postmodernity must emerge - postmodernist art tends to be highly commercialized. In Wood's (1997) words, we would be inclined to say that art did not escape from the expansion of capitalism, not only across the globe, but across fields of culture.

\begin{tabular}{|l|l|l|}
\hline late $19^{\text {th }} \mathrm{c}$ & early $20^{\text {th }} \mathrm{c}$ & late $20^{\text {th }} \mathrm{c}>>$ \\
\hline & $\begin{array}{l}\text { modernism in architecture } \\
\text { (the International Style) }\end{array}$ & $\begin{array}{l}\text { postmodernism in } \\
\text { architecture (incorporation of } \\
\text { 'local' cultural elements) }\end{array}$ \\
\hline \multicolumn{2}{|l|}{ modernism in the arts (various avant-garde movements) } & postmodernism in the arts \\
\hline
\end{tabular}

Table 3: Modernism and postmodernism in architecture and the arts

\section{Situating fashion in modernity}

How can we situate fashion, with its own obsession with what is modern, in relation to modernity, bearing in mind the complex conceptual landscape of which I have tried to present some central points? But, first of all, why should we care? Clothes are an extremely important aspect of culture. We should remember that, as Faurschou (1988: 78) says, "the adornment of the body has rarely been a question of strict material or functional necessity". Garments have always played a defining role in the marking of differences between people: men and women, urban and rural people, adherents of different religions (even protestant vs. catholic in European history), generations, occupations, neighborhoods. This social and cultural significance of clothing also has a political side: one can impose a dress code as a restriction on one's freedom, one may dress in a way to signal submission or rebellion, or to underscore sameness or difference. These functions are probably as old as human civilization, but it is important to remember that they do not cease to play a role in the periods we want to deal with when discussing fashion specifically in relation to modernity.

The next question is what we mean precisely by fashion. We must specify what the term refers to in order to define its position in relation to modernity. A convenient starting point is Breward's definition: 
Fashion is taken to mean clothing designed primarily for its expressive and decorative qualities, related closely to the current short-term dictates of the market, rather than for work or ceremonial functions. (1995: 5)

As Breward shows, fashion in that sense is a phenomenon that is no doubt pre-modern in origin even if we place the beginnings of the modern age as early as the later decades of the $15^{\text {th }}$ century (see Table 1). Restricting himself to England, he finds historical evidence for fashion in the middle of the $14^{\text {th }}$ century, linked to mercantile capitalism in medieval European cities. In that period, the conscious introduction of differentiation (e.g. according to gender roles), choice, and change can already be traced, and these processes are related to market tendencies.

This is no doubt the way in which fashion continues to develop into the modern age. What is striking in this description is an immediate emphasis on economic factors, the 'market'. Breward mentions 'expressive and decorative qualities', but does not ask the question of what clothing could be an expression of. In what follows I will also focus on the economic embedding of fashion first. But then the wider social, cultural, artistic, and even political significance will also be touched upon. In the context of a discussion of fashion and modernity, those aspects should occupy an important place. Otherwise, we would have to claim that fashion is linked to only one of the pillars of modernity (industrialization and capitalism) and not to broader consequences of Enlightenment thinking (see Table 2).

\section{Fashion in a (post)modern economy}

Differentiation, choice, and change in fashion, which was already observable at least from the $14^{\text {th }}$ century onwards ${ }^{8}$ in the context of mercantile capitalism, underwent a serious transformation in the course of the $18^{\text {th }}$ century. Industrial manufacturing techniques changed the production process, and a stronger commercial orientation produced faster changes. About the $19^{\text {th }}$ century we read:

Violent changes in the broader scenario of production and consumption were also reflected in the style and the form of fashionable dress itself, which in terms of variety and complexity underwent something of a visual transformation. (Breward 1995: 147)

\footnotetext{
${ }^{8}$ Note that such historical statements are based on research carried out on developments in European fashion. Maybe completely different statements would have to be made in relation to developments elsewhere, as for instance in Asia.
} 
Indeed, certain clothing shapes could not have been produced so easily without the role of industrial and technological progress. The production of steel, for instance, made it possible to create the flexible cage frames of the wire crinoline. Though their popularity was short-lived, the wire was produced on a large scale, and there was a clear link with efforts at protecting newly invented products and designs; patents were taken out for crinolines and so-called 'skirt improvers' in the period 1847-1870. Another example is the invention of aniline dyes, which made it possible to produce fabrics in colors such as purple and mauve which had been very hard to obtain before.

Possibilities of industrial mass production went hand in hand with trading methods oriented to finding cheaply produced goods in large quantities, sold quickly with small profits. Serious business empires were built that way, for instance by James Morrison in the first half of the $19^{\text {th }}$ century (see Dakers 2005). At the level of trade, there were also two other innovations, the department store and fashion magazines:

The rise of the department store and the expansion of women's fashion magazines, both designed to serve all classes, undoubtedly transformed and 'modernised' the culture and consumption of dress in the second half of the century. (Breward 1995: 166)

By 1870, Le Bon Marché was well-established in Paris and the model was soon adopted elsewhere in Europe, especially in London. The purpose of department stores was to put on display the widest range of new branded fashionable goods at fixed prices. They made it possible to browse goods that had to be displayed in such a way as to make them compete for attention. Having different products available thus became a necessity. This development went together with the rise of a middle class of (mostly male) white-collar workers whose wives had some money to spare and for whom shopping was a welcome break from the chores of the home and for whom consumption became part of their bourgeois identity. Also men consumed fashion, but with the exception of the obvious excesses of dandyism (with Beau Brummell as an early prototype) they were more 'hidden' consumers (see Breward 1999); there were, for instance, no male fashion magazines until the 1920's.

Yet, however strongly fashion may be associated with the rise of industrial capitalism, both in terms of production and of trading, its position in relation to those economic developments is not unambiguous. There are at least three specific developments that modify the picture.

First, in spite of large-scale production and trading, clothes-making required a serious amount of detailed and mostly manual labor which, in turn, made it possible to preserve a high degree of differentiation. Quoting Styles, 
Dress, despite all the links that scholars have made between it and a variety of modernities, never fitted easily into those narratives of economic history whose culmination was Fordist mass production. Economic historians wrote extensively about how clothing materials were manufactured, but with few exceptions their [p. 34] histories concluded at the textile factory gate. The production of clothing itself was too fragmented, too small-scale, too primitive to incorporate into their grand narratives of industrial progress. But with the undermining of those grand narratives and the reassertion of the small-scale, the flexible and the diverse, the distinctive, fashiondriven features of the way clothes are made appear less a historical backwater than one of the main currents in the history of modern manufacturing. (Styles 2005: 34-35)

Whether or not we go along with Styles' suggestion that similar processes can be observed in other areas of manufacturing, this picture is certainly correct for the fashion industry. We must remember that even though steel wire for the crinoline was really factory-produced, once the wires were there and had been cut at specific lengths, the pieces went to workshops where the cage frames were manually constructed.

A second remark pertains to the way in which heavy industry itself facilitated smallscale home production. From the early 1850's, sewing machines were manufactured. These were soon adopted for home alterations of pieces of clothing. And by 1865 free dress patterns for home production were distributed with the fashion magazines. In other words, small-scale production was itself stimulated by the availability of machines that large-scale industry provided.

Third, the $19^{\text {th }}$ century witnesses the emergence of the 'designer' as a profession. Fashion design as a specific professional role aimed at the creation of differences and changes in style, is generally assumed to date from the middle of the $19^{\text {th }}$ century. The British Charles Frederick Worth is often presented as the first real 'fashion designer'. In 1858 he established the first real 'haute couture' house in Paris. What distinguished him from the 'tailors' before him was that he did not just make the clothes that customers wanted him to make. Instead, he decided what he would make for whom and how. In other words, he really 'designed' their clothes. This activity, by definition, does not fit the picture of industrial mass production. Still it suits ideas of modernity: tradition is consciously deviated from in a search for new forms adapted to the individual

All these properties of the positioning of fashion in an economy of modernity continue into the $20^{\text {th }}$ century and until the present day, with an ever stronger incorporation of fashion in a general world-wide consumer culture. There is a vast expansion of the market for fashion magazines, supplemented with websites and blogs. There is the increased role of the mass media, starting with the Hollywood film after 1920, but generalized through television and the internet: sales of a fashion line boom when a celebrity is seen to wear a certain brand. Chain stores have multiplied, and so have mail order companies (these days mostly internet-based). 
And fashion is produced and marketed by giant multinational corporations, ranging from cheaper single-brand companies (H\&M, Zara, etc.) to business conglomerates at the high end of the fashion scale (such as LVHM). This does not mean that smaller businesses have disappeared:

At the same time, paradoxically, a reorganisation of business practices, or marketing and advertising, prioritised particular strands of society as fashion leaders. A cult of 'the designer' revolving around ideals of couture and 'high fashion' or strong subcultural identities ensured the survival of older hierarchies based on notions of quality, style and individuality [...]. (Breward 1995: 183)

The paradox here, however, is not simply an opposition between mass production and smaller (and more expensive) labels. Mass production and distribution with small profit margins is obviously in line with the industrial trends since the $18^{\text {th }}$ century. Affordable products are made, which seems democratic, but such quantities are produced that really big capital is required, and profit margins are handled that are often made possible only by economic exploitation on the production side. But breaking away from this pattern by single designers or small design teams makes clothes more expensive, and the survival of designer brands requires consumers with more buying power. Thus fashion seems trapped in a truly (post)modern capitalist economic logic at both ends. This picture looks even worse when the effect of advertising and image building is taken into account: some conglomerates with serious capital reserves incorporate expensive brands that have achieved such a status in the hierarchy of desirability that high profit margins can be maintained without harming the expansion of sales. When looking at the economic side it is hard, therefore, not to side with Wood's emphasis on the expansive influence and continuity of a capitalist model in the modern and postmodern world, rather than to assume a significant break between modernity and postmodernity (see Table 2).

\section{Fashion, social status, and politics}

As said before, garments have always played a defining role in the marking of social differences between people. This universal phenomenon manifests itself in specific ways since the $18^{\text {th }}$ century. At the earliest stages of industrial manufacturing, clothes were beginning to signal the difference between members of the rising bourgeois classes on the one hand and the old aristocracy on the other. In the beginning, bourgeois dress reflected mostly rather conservative values: durability (based on the high quality of the manufactured materials) and modesty (though not neglecting elegance). With the fading role of aristocratic 
elites, this original distinction became much less outspoken. Many types of new distinctions emerged over time, others became more outspoken, and still others disappeared, often in conjunction with modern social developments.

One of the more striking developments may have been that in the $19^{\text {th }}$ century the difference between male and female dress became more visible. Male dress was inspired by earlier aristocratic sportswear (with tight-fitting pants reminiscent of riding outfits). Female dress was beginning to place much more emphasis on female elegance, also in public, where it was no longer obligatory to hide behind a cloak and veil. Such gender differences, while persisting, have also been played around with in many ways: the introduction of trousers for women from the $19^{\text {th }}$ century onwards, the emergence of androgynous fashions for men as early as the 1920 's, and so on.

In addition to fluctuating ways of signaling gender roles, social status differences manifested themselves in dress in varying ways. In the modern cityscape is has always been possible to distinguish, on the basis of dress as much as behavior, bourgeois passers-by from street vendors, from shopkeepers, from office workers, from factory workers, and so on. And even though today well-made fashionable clothes are widely accessible for many people in western societies, it does not take much training to distinguish those who can afford (or choose to invest in) luxury brands, even if the products are not conspicuous and worn with modesty.

Clothes may of course also be chosen and worn to make explicit statements of distinction or of belonging. The phenomenon of 'uniforms' ranges from the unchangeable aspects of clothing which are self-prescribed by certain ethnic or religious groups (whether Amish, Sikhs, or Hasidic Jews) to the garments of a variety of occupations (e.g. nurses, whose uniforms have themselves undergone fashion changes over the years). Any type of uniform signals one's belonging to a group. But belonging itself is also a matter of being distinct from others. And distinctness can be explicitly emphasized with what Wilson (2003: 179-207) calls 'oppositional dress'. In this context, Wilson also shows the fundamental ambivalence of fashion as a social, and in many ways political, phenomenon: forms of opposititional or rebellious dress may become highly 'fashionable' and even set the norms for later standard developments.

A first example of this we can already find in late $18^{\text {th }}$ and early $19^{\text {th }}$ century dandyism. When political upheavals made aristocratic birth and wealth less relevant, dandies consciously sought social distinction in style and pose. They paid extreme attention to what they were wearing, being careful to not to look conspicuously adorned. Their style, which is often referred to as a style of 'understatement' or even 'anti-fashion' in dress, also included the introduction of adaptations of earlier aristocratic sportswear. Though their habits of spending hours polishing their boots or deciding how to knot their ties did not spread widely, the resulting inconspicuous and laid-back style set the tone for much of the later development of men's fashion - turning men, in Breward's terms, into somewhat hidden consumers of fashion rather than a species not interested in fashion at all. 
Another example would be the 'bohemian' style which developed in the early $20^{\text {th }}$ century in London's Chelsea and New York's Greenwich Village. The inhabitants of these areas, artists, writers, journalists, consciously challenged reigning bourgeois norms, for instance by leaving off hats at a time when all men and women were wearing them, by not using cosmetics, by letting women wear either men's clothes or flowing robes, etc. But soon this radicalism turned into a new form of consumerism, because the rebellious dressing habits became fashionable themselves. The same can be said of the black colors that were worn by beatniks as a statement of dissent, or of the hippie style that emerged as an aspect of student counterculture. Hippies' use of second-hand clothes, for instance, was not without its own paradoxes:

Yet although this was undertaken in a spirit of anti-consumerism, it did involve the expenditure of much time if not money, and reintroduced the snobbery of uniqueness, since there was, necessarily, only one of the 'frock' you had found - just as much as if you'd bought a Dior original. (Wilson 2003: 193)

About the introduction of unisex dress, itself related to the sexual revolution of the 1960's, Suzy Menkes is said to have remarked as early as 1984

[...] that this form of 'cross-dressing', which is opening up the way to 'genderbending' unisex departments in exclusive fashion stores, is simply a new fad and that - significantly - the market it is aimed at is the market of affluent heterosexual couples for whom androgynous dress symbolizes not an attack on gender but merely a reaffirmation of middle-class togetherness. (Wilson 2003: 203)

Looked at in this way, there seems no escape from patterns of social dominance. Some analysts have made the link with political power relations. Particularly popular are illusions to the relationship between Parisian fashion houses and the Nazi occupiers during the Second World War. The recent commotion surrounding John Galliano's "I love Hitler" scandal and his subsequent dimissal from Dior made Peter Popham write an article entitled "Fashion and fascism - a love story" for The Independent on Sunday (6 March 2011, p. 48). He claims that the fashion industry's vulnerability when there are allusions to fascism (and hence the quick dismissal of Galliano) simply result from the fact that it does not want to be reminded of a history of past collaboration. Some even go further: there was a comment on the incident saying that the ideals of beauty that are stimulated by the fashion industry are inherently comparable to Nazi ideology aimed at the creation of a pure and perfect breed of human being 
Without denying the paradoxical status of fashion in relation to economic and social structures, and hence inevitably to politics as well, we must remember that

[...] because fashion, like capitalism itself, is so contradictory, it at least has the potential to challenge those ideologies in which it is itself enmeshed - as can all popular cultural forms, so long, that is, as we have some coherent political position [...] from which to criticize. (Wilson 2003: 205)

In this sense, fashion can even play a fundamental role in the further development of modernity in Habermas' interpretation of it as an unfinished Enlightenment project (see Table 2).

\section{Fashion and individuality}

As we have seen, modernity and postmodernity are closely associated with developing notions of subjectivity. Even if a postmodern logic no longer sees the individual subject as a member of a universal human category with shared rationality, and even if people are no longer conceived as having a clear identity but rather as displaying mutable performances of identity, an emphasis remains throughout the (post)modern period on individual responsibility, choice, and positioning. Not surprisingly, the relationship of fashion with individuality is as ambivalent as its relation with the economy and social structures. Group identity and conformity, as well as individual identity and self-expression, all play a role. According to Hill (2005), in the world of clothes, sameness dominates, the apparent opposite of individuality. Observing similarities in dress in a modern city, he observes:

Perhaps though what people were wearing was indicative of the type of individuals they had become - adrift in a world of consumption, without direction, context and meaning. (Hill 2005: 75)

He adds:

This offers an intriguing perspective on the state of the contemporary individual dressing in a way that signifies very little, but at the same time anxious about what they are wearing. (Hill 2005: 76) 
However, the opposite may be stressed as well:

Twentieth-century fashion, rather than producing a sense of undifferentiated sameness, has actually supported fashion changes as frenetic and diverse, as open to the possibilities of individuality, as any other period. (Breward 1995: 184)

Some analysts formulate this in extremely negative terms:

In contrast to the productivist ethic of industrial modernism, late capitalism is the society of consumption, the society of the mass market and multinational capital, the age of media, information, and electronic reproduction. It is no longer an economy seeking to fulfill the needs of a modernizing society but a society driven to create a perpetual desire for need, for novelty, for endless difference and instant satisfaction. (Faurschou 1988: 82)

What is referred to here is the logic of planned obsolescence: these days, industries have a tendency to produce things in such a way that they are outdated very soon so that they need to be replaced by newer products. Faurschou (1988: 92), thinking about the fast seasonal changes in fashion, goes as far as to say that "[...] fashion has become the commodity "par excellence"". This verdict ignores the entire range of electronic gadgets, where the need for trend followers to always possess the newest item seems a lot stronger. In that field, moreover, the choice of 'newest items' is more restricted, and an item that gets outdated loses its value (and often even its usability) completely. Fashion is notably different: even someone really trying to keep up with fashion trends must constantly choose between styles and items that best suit his or her personal tastes, so that individuality remains an important factor, and one can always go back to pieces of clothing from earlier seasons when choosing something to wear on a specific occasion. Obsolescence, in other words, cannot be truly planned in the world of fashion.

Similarly, thinking about fashion in exclusively negative terms as reducing the body to a perfect 'object' without meaning, completely stripped of human individuality and personality, so that it could as well be replaced by a lifeless mannequin ${ }^{9}$, seems extremely one-sided. ${ }^{10}$

\footnotetext{
${ }^{9}$ Such views are attributed to a theorist of postmodernity such as Jean Baudrillard.

${ }^{10}$ For a balanced account of fashion as an expression of individual identity (in relation to gender roles, social status, sexuality), see Davis (1992).
} 


\section{The artistic and cultural positioning of fashion}

There is no need to deny that fashion occupies an ambivalent position in relation to economic processes, social structures, and even ideas of individuality, and that this positioning is related to aspects of modernity that often have negative as much as, if not more than, positive sides. But its being embedded in a capitalist economy (as simply as aspect of money culture and conspicuous consumption - cf. Veblen 1953), and the strong potential it carries for marking social class distinctions (as analyzed by Bourdieu 1979), certainly are not the only things that need to be emphasized when trying to make sense of the relation between fashion and modernity. In other words, fashion is not just an overheated piece of international economic machinery that is permanently in 'fast forward' mode. It is true that

[...] fashion is a space where industry articulates issues of identity and signification for the purposes of competitive advantage to such a degree that culture and economy become mutually constitutive to the extent of being analytically inseparable. (Briggs 2005: 81)

But it is important to also emphasize the cultural side of the equation, and in particular the artistic status of fashion.

Particularly helpful is Lipovetsky's (1987) study of fashion in which he places, as Breward (1995) does, the origins of fashion at the end of the $14^{\text {th }}$ century, about a century before what historians call the modern age (see Table 1). He adds that, roughly speaking, there are two periods to be distinguished in the history of fashion: from the $14^{\text {th }}$ century until about 1850 , and the period from 1850 onwards to the middle of the $20^{\text {th }}$ century. This distinction is adopted by Stern (2004) to delimit the period of his own study of clothing as art: 1850-1930. Note that this period starts roughly with Baudelaire's reference to fashion prints to illustrate his view of beauty in modernity as historical and changeable rather than universal and absolute, and coincides with the period of modernism in art (see Table 3). One defining property of the period, for Lipovetsky, is the fact that, with the establishment of haute couture houses (Worth being the first in the 1850's), fashion becomes a form of art. Recognition as art leads to an integration of fashion in the modernist avant-garde art scenes:

[...] after Baudelaire, the debate over fashion only became more intense. It involved controversies over fundamental issues in the art theory and aesthetics of the second half of the nineteenth century, including the abolition of the traditional hierarchy between 'major' and 'minor' arts, a questioning of the difference in 'status' of artists 
and craftsmen, and the artist's wish to go beyond the traditional boundaries of art. For many artists at the end of the nineteenth century and the first half of the twentieth, dress design was something far too important to be left to couturiers alone. The historical avant-gardes would appropriate dress design as a privileged field in which the artist could overstep the limits of 'pure' art and act directly on daily life.

These artists' dress proposals are very diverse in terms of style, but they all proceed from a common will to reject 'official' fashion, refusing its mercantile logic and striving to replace it by a utopian 'antifashion'. (Stern 2004: 3)

In this way, fashion came to share the artistic goals of avant-garde art movements. Stern describes, by way of illustration:

- French romanticims and its movement from individual eccentricity to artistic dress;

- rational, artistic, and aesthetic dress in England

- Henry van de Velde's fashion designs based on principles comparable to his modernist architecture (and to their integration in an environment that could be seen as a Gesamtkunstwerk)

- designs by Gustav Klimt and the members of the Wiener Werkstätte

- Giacomo Balla's futurist dress designs

- the utility-oriented dress style of the Russian avant-garde

- Sonia Delaunay's experiments with 'simultaneous dresses' (incorporating a diversity of materials, shapes, and colors)

None of these developments were accidental. They were carefully thought about, as appears from the writings by many of the protagonists, collected in Stern's Against Fashion. In other words, just like developments in painting, sculpture, and architecture, developments in fashion were meant to be meaningful, expressing ideas about beauty and attitudes to society, social trends and structures. An explicit discussion of many of the issues can for instance be found in a work by another modernist architect, Le Corbusier, L'art décoratif d'aujourd'hui (1925), which Wigley (1995) uses as his starting point for a lengthy account of the relations between modernist architecture and fashion, which both also represent a field of tension between art and technique in attempts to create interesting new forms with relatively simple variations and without directly aiming at ornament.

The link between fashion and art goes beyond the work of artists who ventured into fashion. There are numerous examples of fashion designs inspired by works of art. But more importantly, designers and visual artists share both goals and methods. As to goals, they all try to bring an innovative visual message which cannot necessarily be formulated in words but which is nevertheless pertinent to people's lives. As Wilson puts it: 
Art is always seeking new ways to illuminate our dilemmas; dress, however tainted a medium - from its association with the body and with daily life and behaviour nevertheless does this too. (Wilson 2003: 247)

As to methods, designers and artists alike get their inspiration from all areas of experience, including older art (which is why progress is sometimes made by moving cyclically rather than straight ahead). As Brassett (2005) suggests, a useful notion to understand fashion, as well as art, may therefore be the notion of 'emergence': in creative processes the whole becomes more that the sum of the parts, and there is a form of self-organization at work; changes may happens without direct outside input, and qualitative changes of direction may unintentionally grow out of a struggle with sources of inspiration, ideas, techniques, materials, and all their limitations.

When discussing recent developments, Wilson (2003) observes that haute couture may be losing the dominant leadership position it once had. Fashion shows usually run at a loss, presenting clothes that are hardly sold but that serve as expensive advertisement for more affordable ready to wear and derived products such as cosmetics and accessories. In her opinion, this development brings fashion even closer to the art world. A symptom may be the frequency with which fashion is featured in museums nowadays. New may be the fact that not only the traditional visual arts are involved these days, but a strong performance element is introduced as well.

\section{A complex picture}

When Obama was running for the US Presidency, there was a New York homeless man trying to appeal to passers-by with a cardboard sign saying "I'm just like Obama - I want change". There might be a temptation to use this man's play on the polysemy of 'change' as a metaphor for the fashion world: innovation, yes, but with money as the driving force. The importance of the economic side cannot be downplayed. It is certainly the dominant factor from the point of view of the fashion trade. But the phenomenon of fashion is not that simple, especially from the designer's perspective. A designer's basic, and highly complex, question is: what can be made how and where in a sufficiently creative and innovative way, appealing to people's ambivalent needs for identity, conformity, and individual self-expression, and producible in an affordable and ethical manner? This formulation of what is both an artistic and a practical problem addresses all parameters of modernity (and postmodernity, if one wants to use that term). 


\section{References}

Augé, Marc (2009) Pour une anthropologie de la mobilité. Paris : Éditions Payot \& Rivages.

Bindas, Kenneth J. (1990) 'Review of Elizabeth Wilson, Adorned in Dreams'. The History Teacher 24(1): 127-128.

Bourdieu, Pierre (1979) La distinction. Paris : Éditions de Minuit.

Brassett, Jamie (2005) 'entropy (fashion) and emergence (fashioning)'. In Breward \& Evans (eds), 197-209.

Breward, Christopher (1995) The Culture of Fashion: A New History of Fashionable Dress. Manchester: Manchester Univerity Press.

- (1999) The Hidden Consumer: Masculinities, Fashion and City Life 1860-1914. Manchester: Manchester University Press.

— \& Caroline Evans (eds) (2005) Fashion and Modernity. Oxford: Berg.

Briggs, Adam (2005) 'Response'. In Breward \& Evans (eds), 79-81.

Dakers, Caroline (2005) 'James Morrison (1789-1857), 'Napoleon of shopkeepers', millionaire haberdasher, modern entrepreneur'. In Breward \& Evans (eds), 17-32.

Davis, Fred (1992) Fashion, Culture, and Identity. Chicago: The University of Chicago Press.

Delanty, Gerard (2000) Modernity and Postmodernity: Knowledge, Power and the Self. London: Sage.

Faurschou, Gail (1988) 'Fashion and the cultural logic of postmodernity'. In Kroker \& Kroker (eds), 78-93.

Foster, Hal (ed.) (1983) Postmodern Culture. Port Townsend, WA: Bay Press.

Habermas, Jürgen (1983 [1981]) 'Modernity - An incomplete project'. In Foster (ed.), 3-15.

Hauser, Kitty (2005) 'The fingerprint of the second skin'. In Breward \& Evans (eds), 153170.

Hill, Andrew (2005) 'People dress so badly nowadays: Fashion and late modernity.' In Breward \& Evans, 67-77.

Horkheimer, Max \& Theodor Adorno (1979 [1944]) Dialectic of Enlightenment. London: Verso.

Jauss, Hans Robert (1982) Toward an Aesthetic of Reception. Minneapolis: University of Minnesota Press. 
Kroker, Arthur \& Marilouise Kroker (eds) (1988) Body Invaders: Sexuality and the Postmodern Condition. London: Macmillan.

Le Corbusier (1925) L'art décoratif d'aujourd'hui. Paris: Éditions G. Grès et Cie.

Lehmann, Ulrich (2000) Tigersprung: Fashion in Modernity. Cambridge, MA: MIT Press.

Lipovetsky, Gilles (1987) L'empire de l'éphémère: Le mode et son destin dans les sociétés modernes. Paris : Gallimard.

Malpas, Simon (2005) The Postmodern. London: Routledge.

Purdy, Daniel (2004) 'Review of Ulrich Lehmann, Tigersprung'. The Journal of Modern History 76(4): 943-945.

Radford, Robert (2001) 'Review of Ulrich Lehmann, Tigersprung'. The Burlington Magazine 143(1179): 381.

Ray, Larry (1997) 'Post-Communism: Postmodernity or modernity revisited?' The British Journal of Sociology 48(4): 543-560.

Stern, Radu (2004) Against Fashion: Clothing as Art, 1850-1930. Cambridge, Mass.: The MIT Press.

Styles, John (2005) 'Response'. In Breward \& Evans (eds), 33-37.

Toynbee, Arnold (1954) A Study of History, vol. IX. Oxford: Oxford University Press.

Veblen, Thorstein (1953 [1899]) The Theory of the Leisure Class: An Economic Study of Institutions. New York: Mentor Books.

Wigley, Mark (1995) White Walls, Designer Dresses: The Fashioning of Modern Architecture. Cambridge, Mass.: The MIT Press.

Wilson, Elizabeth (2003 [1985]) Adorned in Dreams: Fashion and Modernity. London: I.B. Tauris \& Co Ltd.

- (2005) 'Fashion and modernity'. In Breward \& Evans (eds), 9-14.

Wood, Ellen Meiksins (1997) 'Modernity, postmodeernity or capitalism'. Review of International Political Economy 4(3): 539-560. 